\title{
Comparative Analysis of the Determinants of Residential Land Values
}

\author{
Ilechukwu Victor Uju, Salau Taofik Iyanda \\ University of Lagos, Lagos, Nigeria
}

\begin{abstract}
City development is a result of many factors, of which land value is one of the major determinants. The past urban economics studies have shown that land value is largely determined by location factors such as distance from Central Business District (CBD) ignoring the non-location factors like time of purchase and neighbourhood infrastructures. Therefore, this paper attempts to establish the relative importance of location and non-location factors in the determination of residential land value by positing Onitsha, Nigeria as a case study. Eight hundred and fifty residential housing units were selected and questionnaire administered to the landlords through multi-stage sampling technique. The stepwise regression analysis results showed that non-location factors, especially, time of land purchase, contribute more to the variation in residential land values. The paper suggests the revision of the classical economic theories to represent the conditions of urban areas in developing countries.
\end{abstract}

Keywords: residential land value, location factors, non-location factors

\section{Introduction}

Land has been incorporated in economic theories in various ways as explained by Klaus et al. (2006). Originally, land used by agriculture was the main motivation for economic treatment of land. This is gradually extended with various other land use categories. Today, residential land use, among the various competing urban land uses, is the largest consumer of land in urban areas. That's the reason why the residential land use is usually the focus of urban research. This has been confirmed through the works of many urban researchers like Burgess (1925), Mabogunje (1963), Sada (1995), Frishman (1977), Olaore (1981), Onakerhoroye (1984), Olayiwola, Adeleye, and Oduwaye (2006).

The growth of the economy generates physical development of which residential area is critical. This most often results in increase in land values. Land value is the cost per plot of land. Also, as explained by Lewis (1979), it is the price offered by a purchaser who is aware of price being paid for and asked for other plots or pieces of land in the vicinity at a time when the availability of land is known widely.

Most past studies on urban land values showed that distance from the CBD is the major determinant. That is, land values increase as distance is nearer to the CBD. This is confirmed in studies by the social scientists like

Ilechukwu Victor Uju, Ph.D., Department of Urban and Regional Planning, University of Lagos.

Salau Taofik Iyanda, MSc, MURP, Department of Urban and Regional Planning, University of Lagos.

Correspondence to this article should be addressed to Ilechukwu Victor Uju, Department of Urban and Regional Planning, University of Lagos, Nigeria. E-mail: vicilechuks124@yahoo.com. 
Donnision (1961), Alonso (1964), Yeastes (1965), Brodsky (1970), Ball (1973), Smith (1976), and Asabere (1982). These studies are biased on the sense that the CBD is accorded more importance than it really deserves while the effects of non-location factors like plot size, time of land purchase, age of neighbourhood, income, zoning policy, neigbhourhood quality etc, are neglected.

It is the contention in this paper that land value is also largely determined by the non-location factors. Therefore the paper is aimed at establishing the relative importance of the location and non-location factors in the determination of the residential land values.

\section{Theoretical/Empirical Issues}

It is widely recognized that many theories have been formulated in the study of urban systems. In the area of urban land values, the concept of accessibility has been adopted by scholars to explain the determinants of the values of urban land. These efforts had their origins in the early works of Von Thunen and Ricardo (1893). The principle of bid rent theory was established by Hurd (1903), and this has been confirmed by later works of Ratcliffe (1949), Alonso (1964), and Asabere (1982). The theory as explained by Campbell (1998) refers to how price on real estate or land changes as the distance from the CBD increases. This means that land values decay away from the CBD. However, this statement is contradictory given what have been observed about the suburbanization of both the high and middle income groups, which is facilitated by improved transportation technology.

Based on this observation, recent urban studies have not only shown that land values do not decay away from the CBD but they are also largely determined by non-location factors. Olaore (1991) found that the most important determinants of residential land value in Kaduna were age of neighbourhood and infrastructural index; and that land values increase as one moves away from the CBD. Megbolugbe's (1983) study in Jos showed that structural and neighbourhood attributes are the major determinants of residential housing values. Arimah (1990) added location attributes to the structural and neighbourhood attributes as the determinants of residential housing values in his study in Ibadan. Others studies in Nigeria on the determinants of residential land values in urban areas include those by Okewole (1998), Omirin (1998), Morenikeji (1998), and Olayiwola (2000).

In developed countries, recent studies have shown that fundamentals such as lending interest rates and psychological factors like behavioral expectations are also important determinants of residential land values. Mayer and Sinai (2007) explained that interest rates are capitalized into residential housing prices run-up in U.S.. Also, relating fundamentals to house dynamics in U.S., Brunnermeier and Julliard (2007) developed a dynamic rational expectations model of house price based on interest rate factor. The conclusions of these studies are that interest rates are more important than the distance variables in the determination of residential land or housing values. On the role of psychology, M. H. Smith and G. Smith (2006) concluded that run-up in prices are not fully justified by fundamentals but that pricing inefficiencies are due to high transaction costs that limit arbitrage opportunities for rational investors.

\section{Research Methodology}

To carry out this study, a multi-stage sampling procedure was used. In the first stage, the layouts in Onitsha were stratified into low, medium and high density residential zones. In second stage, 18 major wards of these 
layouts were selected while in the third stage streets in the chosen wards were selected based on their grade and surface conditions. Finally, in the last stage, houses were systematically selected in each street for questionnaire administration. Table 1 shows the number of selected wards and streets as well as number of questionnaires administered in each residential density type.

Table 1

Residential Density Types, Sampling Procedure and Number of Questionnaire Administered

\begin{tabular}{llllccc}
\hline S/N & Density class & Layouts & Wards selected & Streets selected & $\begin{array}{l}\text { Total } \\
\text { questionnaire }\end{array}$ & $\begin{array}{l}\text { Questionnaire } \\
\text { retrieved }\end{array}$ \\
\hline 1 & High density & Fegge & 4 & 21 & 215 & 208 \\
& & Odoakpu & 3 & 15 & 160 & 1,544 \\
& & 1 & 3 & 40 & 21 & 32 \\
\hline & Woliwo & 1 & 3 & 105 & 50 \\
& Okpoko & 1 & 4 & 30 & 29 \\
& Medium density & Omogba & 1 & 2 & 108 & 59 \\
& Awada & 3 & 12 & 51 & 35 \\
& Inland Town & 1 & 4 & 30 & 30 \\
& Otu & American Quarters & 1 & 3 & 20 & 20 \\
\hline Total & G.R.A & 1 & 3 & 850 & \\
\hline
\end{tabular}

Note. Source: The author (2008).

A total of 850 questionnaires were administered and 758 were retrieved. The sample frame was the residential housing unit and the respondents were the landlords or their representatives. The data obtained include socio-economic characteristics, land acquisition, size and cost, housing type, standard, facilities, cost and rent. Others were neighbourhood data such as age, infrastructures and security. In addition, distances of the housing units from the CBD were obtained by map measurement using street map of the city. The data collected were mainly subjected to stepwise regression analysis.

\section{The Case Study Area}

Onitsha city is located in Anambra State in the south-eastern part of Nigeria. The city houses the biggest market in West African. The city has a total population of 256,447 as given by NPC (1991) and consists of 11 layouts, namely, Fegge, Odoakpu, Okpoko, Woliwo, Otu, Inland Town, Awada, Omogba, American Quarters, G.R.A. and Trans Nkisi as shown in Table 1. Onitsha city covers the town itself and a long narrow area of low lying land generally situated between the Niger River and Owerri road extending southwards, with over 2,068 hectares of built up area.

The land use pattern in Onitsha is well defined. The commercial heart which is the Main Market area or central business district (CBD) is located in Otu. This mixed use area is surrounded by the high density residential areas of Odoakpu and Fegge and low/medium density area of American quarters. The low densities residential areas of G.R.A. and Trans Nkisi are found in the north while in east are medium density areas of Omogba, Woliwo and Inland Town. Others are the medium density residential area of Awada located in the east and high density residential area of Okpoko in the South. Land to the south of the expressway from bridge head is largely 
committed by industrial development and also on both sides of Onitsha-Owerri expressway.

The estimated total housing stock in Onitsha by NPC (1991) is 42,500. The housing consists of mainly blocks of flats and bungalow buildings.

\section{Data Analysis and Results}

Comparison of the location and non-location factors in the determination of residential land values.

To compare the contributions of the location and non-location factors, the variables used are first defined and presented in Table 2. The variables consist of quantitative and qualitative or dummy data. The purpose of the comparison is to establish the relative importance of location and non-location factors in the explanation of the spatial variations in land values. The location and non-location variables are entered in the stepwise regression analysis and $R^{2}$ change is used to examine which variables have more effects.

Table 2

Definition of Variables Used in the Regression Analysis

\begin{tabular}{|c|c|c|}
\hline $\mathrm{S} / \mathrm{N}$ & Variables & Definition \\
\hline 1 & Land value (LV) & Cost per plot of land (in Naira) \\
\hline 2 & Distance from CBD (d CBD) & Distance of plot/house unit from CBD (in meter) \\
\hline 3 & Distance from major road (d MR) & Distance of plot/house unit from CBD (in meter) \\
\hline 4 & Plot size (PLS) & Area of plot of land (in $\mathrm{m}^{2}$ ) \\
\hline 5 & Number of rooms (NRM) & Number of rooms in a building \\
\hline 6 & Time of land purchase (TLP) & Period of time when land is purchased (in years) \\
\hline 7 & Date of development (DOD) & Period of time when house is developed (in years) \\
\hline 8 & Age of layout (AOL) & Period of time when layout is developed (in years) \\
\hline 9 & Income per month (INC) & Amount of money per month (in Naira) \\
\hline 10 & Place of origin (POO) & $=1$ if non-native or 0 otherwise \\
\hline 11 & Density zone type (DZT) & $=1$ if located in low density or 0 otherwise \\
\hline 12 & House type (HOT) & $=1$ if blocks of flats or 0 otherwise \\
\hline 13 & Kitchen type (KIT) & $=1$ if separate or 0 otherwise \\
\hline 14 & Bathroom type (BAT) & $=1$ if tub/shower or 0 otherwise \\
\hline 15 & Toilet type (TOT) & $=1$ if water closet or 0 otherwise \\
\hline 16 & Housing wall condition (HWC) & $=1$ if not crack or 0 otherwise \\
\hline 17 & Housing roof condition (HRC) & $=1$ if not leaking or 0 otherwise \\
\hline 18 & Road condition (ROC) & $=1$ if tarred or 0 otherwise \\
\hline 19 & Number of primary school (NPS) & Number of primary schools in a layout \\
\hline 20 & Number of health clinic (NHC) & Number of health clinics in a layout \\
\hline 21 & Number of security types (NST) & Number of security types in a layout \\
\hline
\end{tabular}

Note. Source: The Author (2008).

That is, $R^{2}$ change is used to examine the contribution of each variable to the overall explained variance. The results of the stepwise regression analysis of both location and non-location variables for land values are presented in Table 3.

The results show that the $F$ value of 110.324 for land values is highly significant at 0.05 level and eleven variables are considered important. This implies that the eleven independent variables collectively account for the variations in land values and that $R^{2}$ values obtained are not chance occurrences. The $R^{2}$ change shows that the most important variable is time of land purchase (TLP), which accounts $47.9 \%$ of the spatial variations in the land 
values. The TLP coefficient shows that an increase in the number of years when land is purchased would result to a $0.39 \%$ decrease in land values. The next most important variables are bathroom type (BAT), distance from the major roads (dMR) and house type (HOT), which respectively contribute $6.2 \%, 2.7 \%$ and $1.91 \%$ to the explanation of the variations in land values. The other seven variables, including distance to the CBD, (dCBD) are not too significant and important because they contribute less than $1 \%$ of the variations in land values. However, the dCBD coefficient shows that an increase in the distance from the CBD would result in a $0.08 \%$ increase in land values. This implies that land values do not decay away from the CBD unlike the findings of Alonso (1964), Ball (1973), and Asabere (1982).

Table 3

Stepwise Regression Analysis (Location and Non-location Variables): Land Values

\begin{tabular}{llllllll}
\hline Step & Variables entered & Multiple $R$ & $R^{2}$ & $R^{2}$ change & Regression coefficient & $t$-value & Sign. level \\
\hline 1 & TLP & 0.692 & 0.479 & 0.479 & -0.390 & -6.073 & 0.000 \\
2 & BAT & 0.736 & 0.541 & 0.062 & 0.190 & 5.887 & 0.000 \\
3 & dMR & 0.755 & 0.568 & 0.027 & 0.097 & 2.543 & 0.011 \\
4 & HOT & 0.767 & 0.587 & 0.019 & 0.253 & 7.175 & 0.000 \\
5 & ROC & 0.772 & 0.594 & 0.007 & 0.090 & 3.674 & 0.000 \\
6 & KIT & 0.776 & 0.599 & 0.005 & -0.187 & -4.146 & 0.000 \\
7 & INC & 0.780 & 0.604 & 0.005 & 0.083 & 2.879 & 0.004 \\
8 & NHC & 0.782 & 0.608 & 0.004 & -0.061 & -2.622 & 0.009 \\
9 & AOL & 0.785 & 0.611 & 0.003 & -0.174 & -3.096 & 0.002 \\
10 & DOD & 0.786 & 0.613 & 0.002 & -0.156 & -2.402 & 0.017 \\
11 & dCBD & 0.788 & 0.615 & 0.002 & 0.081 & 2.029 & 0.043 \\
\hline$F$ value & 110.324 & \multicolumn{7}{c}{} & &
\end{tabular}

Arising from the results of this analysis, time of land purchase (TLP), which is non-location variable, is more important in the explanation of the spatial variations in land values.

\section{Conclusion and Implications}

This paper has analysized the location and non-location factors influencing residential land values in Onitsha city. This has been done with respect to the different residential neighbourhoods during which reasons for the observed views were established. The use of the stepwise regression analysis made it possible to establish the relative importance of the location and non-location factors in the explanation of the spatial variations in land values. The paper concludes that the non-location factors, especially the time of land purchase, are the most important determinants of residential land values than the distance variables. Also, it shows that land values do not decay away from the CBD.

The theoretical implications of the findings indicate the need to revise the classical urban economic theories, especially the bid rent theory, to represent contemporary conditions of urban areas in developing countries, in particular. This is because the economic development as manifested in urban land use patterns in most developing countries today, are continuously being modified through changes in size and composition of city population, level and distribution of income, road and information development, social organization and economy of living community, as well as the government policy. 


\section{References}

Alonso, W. (1964). Location and land use. Cambridge, Mass: Harvard University Press.

Arimah, B. C. (1990). An analysis of urban housing market in developing country: A case study of Ibadan, Nigeria (Ph.D. thesis submitted to Department of Geography, University of Ibadan, Ibadan).

Asabere, P. K. (1981). The determinants of land values in an African city: The case of Accra, Ghana. Land Economics, 57(3), 385-397.

Ball, M. J. (1973). Recent empirical work on the determinants of relative house price. Urban Studies, 10, 213-233.

Brunnermeier, M., \& Julliard, C. (2007). Money illusion and housing frenzies. Review of Financial Studies (forthcoming).

Burgess, E. W. (1924). The growth of the city_An introduction to a research project (R. E. Park, et al. (Eds.), p. 61). Chicago: The University of Chicago Press.

Frishman, A. I. (1977). The spatial growth and residential location pattern of Kano, Nigeria (Ph.D. thesis submitted to Department of Economics, North Western University).

Hurd, R. (1903). Principle of city land values. New York: Guide.

Klaus, et al. (2006). Changing concept of land in economic theory: From single to multi-displinary approach. Ecological Economics, 56(1), 5-27.

Lewis, J. P. (1979). Urban economics: A set approach. London: Edward Ashnold Publish Ltd..

Mabogunje, A. L. (1968). Urbanization in Nigeria. London: University of London Press.

Mayer, C., \& Sinai, T. (2007). Housing and behavioral finance. Conference paper on Implications of Behavioral Economics.

Megbolugbe, I. F. (1983). An hedonic index based model of housing demand for third world cities (Ph.D. thesis submitted to Department of City and Regional Planning, University of Pennsylvania).

National Population Commission. (1991). Population census of Nigeria.

Olaore, G. O. (1991). Values of land and rentage of shelter in Nigeria's urban areas: A case study of Kaduna. NISER Monograph Series,19, 1-86, Ibadan.

Olayiwola, L. M., Adeleye, O., \& Oduwaye, A. (2006). Spatial variation in residential land value determinants in Lagos, Nigeria. 5th FIG Regional Conference, Accra, Ghana.

Omirin, M. M. (1998). Land accessibility and low income house building activity in metropolitan Lagos. The Lagos Journal of Environmental Studies, 4(1), 1-6.

Onorkerhoraye, A. G. (1984). An introduction to the history of geographic thought. The Geography and Planning Series of Study Note, University of Benin, Nigeria.

Sada, P. O. (1975). Residential land use in Lagos metropolis: An inquiry into relevance of traditional models. African Urban Notes, $\operatorname{vii(1),~6-10.~}$

Smith, M. H., \& Smith, G. (2006). Bubble, bubble, where’s the housing bubble? Brookings papers on Economic Activity.

Yeates, M. H. (1965). Some factors affecting the spatial distribution of Chicago land values, 1910-1960. Economic Geography, 41, 57-70. 